\section{A dimensão ética do trabalho profissional nos hospitais de custódia e tratamento psiquiátrico}

The ethical dimension of the professional work in custody and psychiatric hospitals

\section{Fátima Grave Ortiz}

Fruto da tese de doutorado da autora, a importante obra que se apresenta nesta resenha expressa o acúmulo que o Serviço Social tem experimentado nos últimos trinta anos, mais precisamente com a "virada" do Serviço Social brasileiro em face de sua trajetória e herança conservadora. Como sabemos, a "virada" proporcionou ao Serviço Social a constituição efetiva de um novo projeto de profissão, com desdobramentos para a organização política das entidades da categoria, com impactos sobre a formação e o exercício profissionais.

No tocante ao exercício da profissão, os debates em torno da constituição de uma nova lei de regulamentação e de um novo Código de Ética proporcionados pelo então, já reno-

\footnotetext{
* Mestre e doutora em Serviço Social pela Universidade Federal do Rio de Janeiro (UFRJ). Atualmente, é docente da UFRJ - Rio de Janeiro/RJ, Brasil, e pesquisadora do Núcleo de Estudos e Pesquisas sobre os Fundamentos do Serviço Social na Contemporaneidade. E-mail: fgrave@oi.com.br.
}

vado, Conjunto CFAS/Cras, consistiram em produtos reais do processo da "virada" e da intenção de ruptura com o chamado Serviço Social tradicional. Assim, ainda que tenhamos conseguido apenas em 1993 a sanção de uma nova lei de regulamentação — a Lei n. 8.662 -, a ética profissional experimentara já nos idos da aguerrida década de 1980 a aprovação de um novo Código de Ética balizador das ações profissionais.

O Código de Ética de 1986, e posteriormente o de 1993, com mais ênfase e maturidade, inauguraram um renovado dever ser ao exercício profissional, uma vez que, rompendo efetivamente com a neutralidade, assumiram a dimensão política da intervenção profissional e colocaram a ética como central na constituição de um projeto profissional organicamente vinculado a um alternativo projeto societário sem exploração e discriminação por raça, etnia, gênero, orientação sexual, condição física e classe social.

Com efeito, o livro que ora se apresenta é herdeiro de todo esse processo de renovação do Serviço Social brasileiro, que tem na ética - entendida como uma "produção humana/social, [...] um campo do conhecimento que dá origem a (e se assenta em)

ideias e concepções que indicam determinadas direções sociais e históricas, condicionadas em suas alternativas pela estrutura econômica e política na vida social" (p. 3) - a condição central para o exercício e a formação profissional vinculados ao projeto profissional, a que se aludiu linhas atrás.

Desta forma, com clara influência das categorias presentes no pensamento marxiano (bem como da tradição marxista, em especial Lukács), a autora concebe a moral como um "meio de regulação das relações dos homens entre si e destes com a comunidade" (p.95), que são, por conseguinte, his- 
tóricas, mutáveis e fundamentadas no trabalho como categoria central do processo de constituição do homem como ser social. Por se dar na esfera ineliminável da vida cotidiana, atravessada por sua natureza superficial, descontínua e imediata (nos termos de Heller) e por suas contradições e disputas, a moralidade suscita a reflexão da ética, esta sim capaz de evidenciar a relação entre o sujeito singular que age moralmente e a universalidade presente no humano genérico.

Tomando como solo tais concepções, a autora resgata de forma consistente e inequívoca os fundamentos da moral e da ética para qualificar a ética profissional como "uma forma particular de materialização — de expressão — da vida moral em sociedade." (p. 98). Assim, a ética das profissões está implicada diretamente com o movimento da sociedade e, consequentemente, com os projetos societários que nela gravitam. É com tal perspectiva que a autora nos apresenta suas preocupações centrais - analisar a possibilidade de concreção do projeto ético-político do Serviço Social a partir da materialização, pela mediação das ações profissionais, dos princípios fundamentais do Código de Ética de 1993. Para tanto, busca captar, mediante a análise das respostas dos assistentes sociais durante as entrevistas, o caráter ético-político da intervenção profissional realizada nos hospitais de custódia e tratamento psiquiátrico do Estado do Rio de Janeiro, este concebido pela autora como "campo de atuação profissional que evidencia interseção de diferentes faces da política social, inserção de diferentes profissionais e abarca de maneira 'emblemática', [...] camadas pauperizadas [...] que costumam recorrer às políticas públicas” (p. 121).

Vale ressaltar que a autora empreende vigorosa análise sobre o campo prisional, conceituado como um "contexto institucional bastante complexo, ou seja, focaliza uma instituição que articula duas realidades deprimentes das sociedades modernas - o 'abrigo de loucos' e a prisão [...]” (p. 3), bem como da trajetória do próprio Serviço Social nessa área que data da década de 1950.

As conclusões a que chega a autora são ao mesmo tempo instigantes e desafiadoras porque revelam o quanto o fortalecimento do projeto ético-político e principalmente seu caráter hegemônico exige que nós assistentes sociais - tenhamos consciência de que tal processo não prescinde do resultado efetivo das ações individuais e coletivas dos sujeitos profissionais, e que, portanto, devem estar além da defesa idealista dos princípios subjacentes ao projeto. O livro demonstra claramente, a partir de seu rigor teórico-metodológico, que não basta a adesão ideal dos profissionais aos princípios que fundamentam o projeto profissional, mas o desvelamento da realidade social e de suas contradições, e isso exige investimento maciço em formação continuada por parte dos profissionais e de sua mobilização e organização política enquanto categoria partícipe de uma classe social determinada — a classe trabalhadora.

\section{Recebido em 25/3/2011 \\ Aprovado em 13/6/2011}

\section{Referência bibliográfica}

FORTI,Valeria. Ética, crime e loucura: reflexões sobre a dimensão ética no trabalho profissional. Rio de Janeiro: Lumen Juris, 2009. 252 p. 